Anna Napiórkowska (D) https://orcid.org/0000-0003-2540-9112

Uniwersytet Mikołaja Kopernika w Toruniu

\title{
WYKONYWANIE PRACY ZAROBKOWEJ W OKRESIE CZASOWEJ NIEZDOLNOŚCI DO PRACY Z POWODU CHOROBY - NOWE MOŻLIWE ROZWIĄZANIA W ZWIAZZKU Z COVID-19?
}

\begin{abstract}
Performing gainful employment during the period of temporary incapacity for work due to sickness-new possible solutions in connection with COVID-19?

The Act of 2 March 2020 on special solutions related to the prevention, counteraction and combating of COVID-19, other infectious diseases and crisis situations caused by them introduced some new regulations relating to the issue of the performance of gainful employment during the period of mandatory quarantine or isolation in house conditions. This article presents these new regulations and analyses whether some specific arrangements can guide any developments in the issue of temporary incapacity for work due to sickness.
\end{abstract}

Słowa kluczowe: system ubezpieczenia społecznego, czasowa niezdolność do pracy, zasiłek chorobowy, ubezpieczony, praca zdalna, COVID-19

Keywords: social insurance scheme, temporary incapacity for work, sickness allowance, insured person, remote work, COVID-19

ASJC: 3308, JEL: H55, K31

Czasowa niezdolność do pracy z powodu choroby jest tradycyjnym zdarzeniem ubezpieczeniowym podlegającym ochronie w ramach systemu ubezpieczeń społecznych ${ }^{1}$. Ochroną obejmuje się tu sytuację, w której choroba staje się przeszkodą w zdobywaniu środków utrzymania, czyniąc ubezpieczonego przejściowo niezdolnym do świadczenia dotychczasowej pracy. Wiąże się to z takim wpływem choroby na zdolność do pracy

1 W pewnej mierze - zresztą niemałej - ochrona tego zdarzenia jest też ujęta w ramach przepisów prawa pracy w związku z wypłatą wynagrodzenia chorobowego przez pracodawców. 
który ma charakter przejściowy, przemijający. Chodzi też o niezdolność do pracy dotychczasowej - stanowiącej tytuł ubezpieczenia. Przy orzekaniu o czasowej niezdolności do pracy należy więc zasadniczo wziąć pod uwagę rodzaj i charakter wykonywanej pracy. Analiza przyjętej przez ustawodawcę konstrukcji czasowej niezdolności do pracy pokazuje także, że niezdolność ta jest ujmowana jako niezdolność całkowita. Nie można zatem być czasowo niezdolnym do pracy, ale tylko częściowo, w ograniczonym zakresie (Szubert 1987, s. 90-91; na temat czasowej niezdolności do pracy: Jędrasik-Jankowska 1983, s. 39, 42-44, 53-56; 2018, s. 274-275; Rączka 2000, s. 14; uchwała Sądu Najwyższego z dnia 20 stycznia 1995 roku, II UZP 38/94, LEX nr 11965; wyrok Sądu Apelacyjnego w Poznaniu z dnia 24 kwietnia 1996 roku, III AUr 42/96, LEX nr 29603).

Zgodnie z art. 6 ust. 2 ustawy z dnia 25 czerwca 1999 roku o świadczeniach pieniężnych z ubezpieczenia społecznego w razie choroby i macierzyństwa (Dz.U. 2021, poz. 1133 tekst jedn., dalej: „ustawa zasiłkowa”) na równi z niezdolnością do pracy z powodu choroby należy traktować niemożność wykonywania pracy w wyniku decyzji wydanej przez właściwy organ bądź uprawniony podmiot na podstawie przepisów o zapobieganiu oraz zwalczaniu zakażeń i chorób zakaźnych u ludzi (ustawa z dnia 5 grudnia 2008 roku o zapobieganiu oraz zwalczaniu zakażeń i chorób zakaźnych u ludzi, Dz.U. 2020, poz. 1845 tekst jedn. ze zm., dalej: „u.z.z.z.ch.z."), niemożność wykonywania pracy na skutek poddania się obowiązkowi kwarantanny, izolacji w warunkach domowych bądź izolacji, o których mowa w przepisach o zapobieganiu oraz zwalczaniu zakażeń i chorób zakaźnych u ludzi, niemożność wykonywania pracy z powodu przebywania w stacjonarnym zakładzie lecznictwa odwykowego w celu leczenia uzależnienia od alkoholu, w szpitalu bądź w innym zakładzie leczniczym podmiotu leczniczego wykonującego działalność leczniczą w rodzaju stacjonarne oraz całodobowe świadczenia zdrowotne w celu leczenia uzależnienia od środków odurzających czy substancji psychotropowych, jak również niemożność wykonywania pracy na skutek poddania się niezbędnym badaniom lekarskim przewidzianym dla kandydatów na dawców komórek, tkanek, narządów. Zgodzić należy się z prezentowanym poglądem, że wszystkie te sytuacje są w jakiś sposób związane z chorobą (albo nawet są chorobą - jak w przypadku uzależnień) i wywołują w związku z tym tego samego typu potrzeby (Jędrasik-Jankowska 1997, s. 17; 2018, s. 276).

Zgodnie z art. 17 ust. 1 ustawy zasiłkowej wykonywanie pracy zarobkowej w okresie orzeczonej niezdolności do pracy jest jedną z sytuacji powodujących pozbawienie ubezpieczonego prawa do zasiłku chorobowego za cały okres tego zwolnienia. W związku $\mathrm{z}$ tym, że wynagrodzenie chorobowe wypłacane pracownikowi przez pracodawcę nie przysługuje w tych sytuacjach, $w$ których pracownik nie ma prawa do zasiłku chorobowego - w razie wykonywania pracy zarobkowej w okresie orzeczonej niezdolności do pracy dana osoba nie miałaby także prawa do wynagrodzenia chorobowego (art. $92 \S 3$ pkt 2 ustawy z dnia 26 czerwca 1974 roku - Kodeks pracy, Dz.U. 2020, poz. 1320 tekst jedn. ze zm.). Wskazany art. 17 ustawy zasiłkowej należy w sposób odpowiedni stosować do świadczenia rehabilitacyjnego (art. 22 ustawy zasiłkowej). Wykonywanie pracy zarobkowej powodowałoby więc również utratę prawa do tego świadczenia pobieranego już po wyczerpaniu prawa do zasiłku chorobowego. Widać więc, że w całej możliwej 
sekwencji świadczeń przysługujących w razie czasowej niezdolności do pracy z powodu choroby (wynagrodzenie chorobowe, zasiłek chorobowy, świadczenie rehabilitacyjne), ustawodawca przyjmuje spójne rozwiązanie.

Zastosowanie sankcji (Jończyk 2006, s. 176) pozbawienia prawa do zasiłku chorobowego $\mathrm{w}$ razie wykonywania pracy zarobkowej w okresie orzeczonej niezdolności do pracy może się wydawać zabiegiem oczywistym. Ubezpieczenia społeczne przecież tradycyjnie łagodzą sytuacje związane ze zdarzeniami, które szkodzą zdolności do pracy (wyłączają ją bądź ją zmniejszają), mają tym samym negatywny wpływ na zdolność do pracy i na możliwość zdobywania środków utrzymania, choć same zdarzenia życiowe mające wpływ na tę zdolność niekoniecznie muszą być niekorzystne. Skoro więc ubezpieczony wykonuje pracę zarobkową w czasie orzeczonej niezdolności do pracy, wydaje się, że zasadne jest, by pozbawiać taką osobę prawa do zasiłku chorobowego. Konstrukcja ta łączy się także z regulacją przewidzianą $\mathrm{w}$ art. 12 ust. 1 ustawy zasiłkowej, zgodnie z którą zasiłek chorobowy nie przysługuje za okresy niezdolności do pracy, w których ubezpieczony zachowuje prawo do wynagrodzenia ${ }^{2}$.

Jak można sądzić, wykonywanie pracy zarobkowej mogłoby się mieścić (choć może nie w każdym przypadku) w przesłance wykorzystywania zwolnienia od pracy w sposób niezgodny z jego celem. Ustawodawca zdecydował się jednak wyodrębnić przesłanki występujące w art. 17 ust. 1 ustawy zasiłkowej. Są one od siebie niezależne i mają charakter samoistny, co potwierdza bardzo bogate orzecznictwo (wyrok Sądu Najwyższego z dnia 20 stycznia 2005 roku, II UK 154/04, LEX nr 175814; wyrok Sądu Najwyższego z dnia 14 grudnia 2005 roku, III UK 120/05, LEX nr 201295; wyrok Sądu Najwyższego z dnia 6 lutego 2008 roku, II UK 10/07, LEX nr 493009; wyrok Sądu Najwyższego z dnia 4 listopada 2009 roku, I UK 140/09, LEX nr 564767). W istocie z każdą z tych przesłanek wiążą się liczne wątpliwości.

Na gruncie ustawy z dnia 17 grudnia 1974 roku o świadczeniach pieniężnych z ubezpieczenia społecznego w razie choroby i macierzyństwa (Dz.U. 1974, nr 47, poz. 280 ze zm., dalej: ,ustawa zasiłkowa z 1974 roku”) oraz obowiązującego wówczas zarządzenia Ministra Pracy, Płac i Spraw Socjalnych z dnia 30 grudnia 1974 roku w sprawie kontroli prawidłowości wykorzystywania zwolnień lekarskich od pracy (M.P. 1974, nr 42, poz. 263) w orzecznictwie istniały rozbieżne poglądy co do tego, czy wykonywanie pracy zarobkowej w jednym zakładzie pracy, przy równoczesnym pobieraniu zasiłku chorobowego w drugim zakładzie, było samodzielną przesłanką utraty prawa do zasiłku, czy też konieczne było jeszcze wykazanie, że praca ta stanowiła czynności uciążliwe, mogące przedłużyć okres niezdolności do pracy, lub była niezgodna z celem tego zwolnienia (uchwała Sądu Najwyższego z dnia 20 stycznia 1995 roku, II UZP 38/94, LEX nr 11965; wyrok Sądu Najwyższego z dnia 10 grudnia 1998 roku,

2 Zgodnie z uchwałą Sądu Najwyższego z dnia 17 lutego 2016 roku (III UZP 15/15, LEX nr 1977620) art. 17 ust. 1 ustawy zasiłkowej nie ma zastosowania do ubezpieczonego, który w okresie orzeczonej niezdolności do pracy uzyskał zaświadczenie lekarskie o odzyskaniu zdolności do pracy i podjął pracę zarobkową, o czym zawiadomiono organ rentowy. 
II UKN 367/98, LEX nr 38913; wyrok Sądu Najwyższego z dnia 11 lutego 1999 roku, II UKN 467/98, LEX nr 477337; odmiennie: wyrok Sądu Najwyższego z dnia 12 sierpnia 1998 roku, II UKN 172/98, LEX nr 34553). Obecnie art. 17 ust. 1 ustawy zasiłkowej stanowi o wykonywaniu pracy zarobkowej, a nie o wykonywaniu innej pracy zarobkowej, co jest zasadniczo odczytywane jako rozszerzenie zakresu tej przesłanki (Rączka 2000, s. 23).

Analiza wielu orzeczeń wskazuje, że zarówno art. 17 ust. 1 ustawy zasiłkowej, jak i wcześniej art. 18 ust. 1 ustawy zasiłkowej z 1974 roku stawały naprzeciw zróżnicowanym i skomplikowanym stanom faktycznym. Począwszy od sytuacji, w której ubezpieczony, pozostając w jednym stosunku pracy, nie zaprzestawał świadczenia pracy z chwilą uzyskania zwolnienia lekarskiego - rezygnował częściowo z jego wykorzystania, przez sytuacje, w których pozostawał w dwóch stosunkach pracy / stosunkach prawnych i świadczył pracę zarobkową lub pewne czynności w jednym miejscu, w drugim korzystając ze zwolnienia lekarskiego. Pojawiały się wątpliwości co do sposobu rozumienia pojęcia pracy zarobkowej (czy wcześniej: innej pracy zarobkowej). W tym ostatnim przypadku istotny wydaje się także problem granicy pomiędzy „pracą zarobkową” a „formalnymi czynnościami” podejmowanymi sporadycznie, wymuszonymi okolicznościami. W judykaturze zwraca się uwagę, że należy odróżnić pracę zarobkową wykonywaną jednoosobowo w ramach działalności gospodarczej od czynności typu formalnoprawnego, do których jest zobowiązany ubezpieczony jako pracodawca. Pracownik, który prowadzi dodatkowo działalność gospodarczą, w razie niezdolności do pracy nabędzie prawo do zasiłku chorobowego, nie tracąc przy tym możliwości uzyskiwania przychodu z tytułu działalności gospodarczej, jeśli aktywność zawodowa zostanie ograniczona do spraw niezbędnych, służących utrzymaniu tej działalności oraz niewykraczających poza jej normalny zakres (por. wyrok Sądu Najwyższego z dnia 4 kwietnia 2012 roku, II UK 186/11, LEX nr 1216851; por. także wyrok Sądu Najwyższego z dnia 17 stycznia 2002 roku, II UKN 710/00, LEX nr 56864; wyrok Sądu Najwyższego z dnia 7 października 2003 roku, II UK 76/03, LEX nr 109913; wyrok Sądu Najwyższego z dnia 5 października 2005 roku, I UK 44/05, LEX nr 195532; wyrok Sądu Najwyższego z dnia 9 października 2006 roku, II UK 44/06, LEX nr 309449; wyrok Sądu Najwyższego z dnia 6 maja 2009 roku, II UK 359/08, LEX nr 687081).

W orzecznictwie w odniesieniu do przesłanki wykonywania pracy zarobkowej zwracano między innymi uwagę, że: 1) z uwagi na specyfikę spółdzielni mieszkaniowej udział w posiedzeniach jej rady nadzorczej - chociaż uprawniający do określonego ryczałtu miesięcznego - nie może być traktowany jako praca zarobkowa (wyrok Sądu Najwyższego z dnia 4 listopada 2009 roku, I UK 140/09), 2) udział w akcjach ratowniczych członków ochotniczej straży pożarnej - chociaż uprawniający do otrzymania ekwiwalentu pieniężnego - nie może być uznany za pracę zarobkową z uwagi na szczególny społeczny charakter funkcjonowania takich jednostek (wyrok Sądu Najwyższego z dnia 14 maja 2009 roku, I UK 351/08, LEX nr 515410), 3) praca zarobkowa nie musi być wykonywana w pełnym wymiarze, a pozytywna kwalifikacja pracy zarobkowej w okresie niezdolności do pracy nie jest uzależniona od faktycznego osiągania zarobku, wynika bowiem z samego podjęcia działań stanowiących realizację obowiązków pracowniczych 
(wyrok Sądu Najwyższego z dnia 6 lutego 2008 roku, II UK 10/07), 4) pracą zarobkową jest każda aktywność ludzka zmierzająca do osiągnięcia zarobku, w tym także pozarolnicza działalność gospodarcza, choćby polegająca na czynnościach nieobciążających w istotny sposób danego organizmu (wyrok Sądu Najwyższego z dnia 5 kwietnia 2005 roku, I UK 370/04, LEX nr 157330).

Przyjęta konstrukcja czasowej niezdolności do pracy, jak również regulacja, zgodnie z którą wykonywanie pracy zarobkowej w okresie orzeczonej niezdolności do pracy jest jedną z sytuacji powodujących pozbawienie ubezpieczonego prawa do zasiłku chorobowego, prowadzi do sytuacji, na które już wielokrotnie zwracano uwage w literaturze przedmiotu. Chodzi na przykład o sytuację osób czasowo niezdolnych do pracy i zatrudnionych w dwóch miejscach pracy, które pod sankcją utraty prawa do zasiłku chorobowego muszą powstrzymać się od wykonywania każdej z prac, nawet gdyby wydawało się, że któraś z nich, o odmiennym rodzaju, mogłaby być wykonywana (Jędrasik-Jankowska 2018, s. 315; także: Napiórkowska 2015, s. 210-211). Problem ten dotyczy zresztą również osób pozostających w jednym stosunku pracy czy wykonujących jeden rodzaj działalności. Kwestią problematyczną będzie więc na przykład sprawdzenie egzaminów, wpisanie ocen do systemu czy kontakt $z$ seminarzystami w formie zdalnej przez nauczyciela akademickiego ze złamaną nogą, jak również wprowadzanie określonych danych do systemu przez główną księgową, która przebywa w domu na zwolnieniu lekarskim z uwagi na dolegliwości związane z biodrem. Aktualna regulacja, zdaje się, nie uwzględnia istniejących przeobrażeń - tego, że coraz częściej w procesie pracy korzysta się z komputerów, że wiele osób - ucząc się przez całe życie - doskonali i różnicuje swoje umiejętności. Również porównanie do ubezpieczenia emerytalnego - w ramach którego promowana jest aktywność - pokazuje, że zasiłek chorobowy wciąż pozostaje świadczeniem ukierunkowanym jedynie na zapewnienie świadczeń w razie czasowej i na dodatek całkowitej niezdolności do pracy. Jest to trochę na przekór obserwowanym tendencjom europejskim promującym aktywność i reintegrację na rynku pracy (Devetzi, Stendahl 2011), jak również ogólnym założeniom ubezpieczeniowym, które powinny w jak najszerszym zakresie uwzględniać element prewencji. W tym kontekście należy podnieść, że już obszar ubezpieczenia chorobowego powinien być obszarem o charakterze prewencyjnym w stosunku do ubezpieczenia rentowego. W ramach ubezpieczenia chorobowego da się zaobserwować stany, które mogą zbliżać się do ograniczonej zdolności do pracy. Stany te z pewnej konieczności, ze względu na przyjęte rozwiązania prawne, zostaną zakwalifikowane jako czasowa (całkowita) niezdolność do pracy. Jak się wydaje, mają na to wpływ w dużej mierze względy organizacyjne. Kwestią otwartą pozostaje to, czy w tym obszarze są możliwe pewne przeobrażenia. Warto zwrócić uwagę na wymuszone szczególną sytuacją zmiany wprowadzane w związku z pandemią COVID-19.

Zgodnie z art. 4e ust. 1 ustawy z dnia 2 marca 2020 roku o szczególnych rozwiązaniach związanych z zapobieganiem, przeciwdziałaniem i zwalczaniem COVID-19, innych chorób zakaźnych oraz wywołanych nimi sytuacji kryzysowych (Dz.U. 2020, poz. 1842 tekst jedn. ze zm., dalej: „ustawa dotycząca COVID-19”) - w okresie obowiązywania stanu zagrożenia epidemicznego bądź stanu epidemii, w szczególnych sytuacjach mających związek 
z zapobieganiem, przeciwdziałaniem oraz zwalczaniem COVID-19, dla zapewnienia niezbędnej pomocy osobom przebywającym w jednostkach organizacyjnych pomocy społecznej świadczących usługi całodobowo, noclegowniach i innych placówkach zapewniających całodobową opiekę osobom niepełnosprawnym, przewlekle chorym bądź w podeszłym wieku (o których mowa w ustawie z dnia 12 marca 2004 roku o pomocy społecznej, Dz.U. 2020, poz. 1876 tekst jedn. ze zm.), jak również przebywającym w placówkach opiekuńczo-wychowawczych, regionalnych placówkach opiekuńczo-terapeutycznych i interwencyjnych ośrodkach preadopcyjnych (o których mowa w ustawie z dnia 9 czerwca 2011 roku o wspieraniu rodziny i systemie pieczy zastępczej, Dz.U. 2020, poz. 821 tekst jedn. ze zm.) - pracownicy, jak również inne osoby świadczące pracę (dotyczy to więc także osób, które nie są pracownikami) poddane tam obowiązkowej kwarantannie mogą za zgodą tych osób świadczyć pracę określoną w umowie oraz otrzymywać z tego tytułu wynagrodzenie. Przepis ten w swej zasadniczej konstrukcji został wprowadzony do ustawy dotyczącej COVID-19 w drodze ustawy z dnia 14 maja 2020 roku o zmianie niektórych ustaw w zakresie działań osłonowych w związku z rozprzestrzenianiem się wirusa SARS-CoV-2 (Dz.U. 2020, poz. 875 ze zm.) i wszedł w życie z dniem ogłoszenia z mocą od 8 marca 2020 roku, choć dopiero w 2021 roku zmieniono jego treść, odnosząc się również do placówek opiekuńczo-wychowawczych, regionalnych placówek opiekuńczo-terapeutycznych i interwencyjnych ośrodków preadopcyjnych.

Wprowadzenie konstrukcji przewidzianej w art. 4e ustawy dotyczącej COVID-19 było powodowane obserwowanym zjawiskiem poddawania kwarantannie całych jednostek wraz z pracownikami. W uzasadnieniu do projektu tej regulacji (druk sejmowy nr 344, s. 51) wskazywano na wymóg zgody danej osoby dotyczący świadczenia pracy w tych szczególnych okolicznościach, precyzując także, że w razie świadczenia pracy w czasie obowiązkowej kwarantanny danej osobie będzie przysługiwało prawo do wynagrodzenia w pełnej wysokości, a nie prawo do świadczeń związanych z niezdolnością do pracy. Ustawodawca, wprowadzając to rozwiązanie, ograniczył je czasowo do okresu obowiązywania stanu zagrożenia epidemicznego bądź stanu epidemii. Z przepisów wynika także wyraźnie, że regulacja ta ma dotyczyć szczególnych sytuacji mających związek z zapobieganiem, przeciwdziałaniem oraz zwalczaniem COVID-19, ma też służyć zapewnieniu niezbędnej pomocy osobom przebywającym we wskazanych w tym przepisie podmiotach. W literaturze przedmiotu słusznie podnosi się więc, że praca taka nie powinna stanowić reguły (Piszczek 2020). Zestawienie analizowanej konstrukcji z przepisami jeszcze do niedawna obowiązującymi w odniesieniu do ubezpieczonych wykonujących zawód medyczny pokazuje także wyraźnie, że ustawodawca nie zdecydował się w analizowanej wyżej konstrukcji na kumulację świadczeń (to jest wynagrodzenia za wykonaną pracę oraz świadczenia w razie czasowej niezdolności do pracy). Zupełnie inne natomiast rozwiązanie ustawodawca przyjął właśnie w odniesieniu do ubezpieczonych wykonujących zawód medyczny, choć nastąpiło to nieco później (to jest od 1 kwietnia 2020 roku) i obowiązywało tylko przez pewien czas (od 5 września 2020 roku nastąpił w tym zakresie powrót do zasad ogólnych).

Przechodząc do wskazanej, już nieobowiązującej regulacji dotyczącej ubezpieczonych wykonujących zawód medyczny, należy przypomnieć, że od 1 kwietnia 2020 roku, 
ustawodawca zdecydował się na wprowadzenie rozwiązania, zgodnie z którym jeśli w okresie podlegania obowiązkowej kwarantannie bądź izolacji w warunkach domowych ubezpieczony wykonujący zawód medyczny (w rozumieniu ustawy z dnia 15 kwietnia 2011 roku o działalności leczniczej, Dz.U. 2021, poz. 711 tekst jedn. ze zm.) świadczył pracę zdalną na rzecz podmiotu wykonującego działalność leczniczą lub udzielał świadczeń zdrowotnych za pośrednictwem systemów teleinformatycznych bądź systemów łączności, nie stosowano w takim przypadku art. 17 ustawy zasiłkowej (art. 4b ust. 2 ustawy dotyczącej COVID-19). Tak jak wskazano wyżej, rozwiązanie to obowiązywało tylko do określonego czasu.

W przypadku ubezpieczonych wykonujących zawód medyczny ustawodawca zastosował znacznie korzystniejszy system ochrony niż w odniesieniu do pozostałych ubezpieczonych. Ubezpieczeni ci mogli więc świadczyć pracę zdalną na rzecz podmiotu wykonującego działalność leczniczą (tylko takiego podmiotu) lub udzielać świadczeń zdrowotnych za pośrednictwem systemów teleinformatycznych bądź systemów łączności, przebywając równocześnie na obowiązkowej kwarantannie bądź podlegając izolacji w warunkach domowych. W tym przypadku świadczenia kumulowały się, co wydaje się zabiegiem nie do końca zrozumiałym.

Powyższa uwaga nabiera szczególnego znaczenia, jeśli zestawi się ją z wnioskami wypływającymi z analizy przepisów przewidujących preferencyjną wysokość świadczeń przysługujących niektórym ubezpieczonym w związku z czasową niezdolnością do pracy (choć to drugie zagadnienie wykracza w pewnym zakresie poza ramy niniejszego opracowania). Przechodząc do zasygnalizowanego problemu, trzeba podnieść, że analiza z jednej strony art. 4g ustawy dotyczącej COVID-19 (przewidującego prawo do zasiłku chorobowego na preferencyjnych zasadach w odniesieniu do ubezpieczonych zatrudnionych w podmiotach leczniczych, a wcześniej art. 4c tej samej ustawy w odniesieniu do ubezpieczonych wykonujących zawód medyczny zatrudnionych w podmiotach leczniczych), a z drugiej strony art. 4ea ustawy dotyczącej COVID-19 (przewidującego prawo do wynagrodzenia chorobowego i zasiłku chorobowego w korzystniejszej wysokości w odniesieniu do ubezpieczonych zatrudnionych w jednostkach organizacyjnych pomocy społecznej świadczących usługi całodobowo, noclegowniach, jak również innych placówkach zapewniających całodobową opiekę osobom niepełnosprawnym, przewlekle chorym bądź w podeszłym wieku) ukazuje niestety, że na gruncie prawa ubezpieczeń społecznych można zaobserwować problem konstruowania przez ustawodawcę korzystniejszego sytemu ochrony w odniesieniu do niektórych, „silniejszych” grup ubezpieczonych. Może się to zbliżać do niebezpiecznego podziału na „lepsze” i „gorsze” ryzyka. Analiza regulacji prawnej ukazuje bowiem, że w odniesieniu do ubezpieczonych zatrudnionych w podmiotach leczniczych (a wcześniej ubezpieczonych wykonujących zawód medyczny zatrudnionych w podmiotach leczniczych) ustawodawca konstruuje system świadczeń oparty na bardziej preferencyjnych zasadach, choć składka na ubezpieczenie chorobowe jest taka sama dla wszystkich ubezpieczonych. Wskazana grupa ubezpieczonych stosunkowo wcześnie uzyskała prawo do zasiłku chorobowego na preferencyjnych zasadach, w pewnym momencie była też możliwa kumulacja świadczeń, 
to jest wynagrodzenia za pracę i zasiłku chorobowego. Dla porównania w przypadku ubezpieczonych zatrudnionych w jednostkach organizacyjnych pomocy społecznej świadczących usługi całodobowo, noclegowniach, jak również innych placówkach zapewniających całodobową opiekę osobom niepełnosprawnym, przewlekle chorym bądź w podeszłym wieku - ustawodawca nie konstruuje tak korzystnego systemu ochrony (Napiórkowska 2021).

Niezależnie jednak od powyższych zastrzeżeń dla rozważanego w niniejszym opracowaniu zagadnienia istotne jest przede wszystkim to, że wprowadzony okresowo art. $4 \mathrm{~b}$ ust. 2 ustawy dotyczącej COVID-19 był przykładem dostrzeżenia przez ustawodawcę, że są możliwe takie sytuacje, w których dana osoba może w pewnym zakresie wykonywać pracę zarobkową, nie tylko przebywając na obowiązkowej kwarantannie, ale także - co ma jeszcze silniejszy wydźwięk - będąc w trakcie izolacji w warunkach domowych, a więc w czasie, kiedy ta osoba jest chora (por. art. 2 pkt 11a u.z.z.z.ch.z.).

$\mathrm{W}$ celu pełnego zobrazowania analizowanego zagadnienia należy jeszcze zwrócić uwagę na kolejne przepisy dotyczące tej problematyki, to jest art. $4 \mathrm{~h}$ oraz art. $4 \mathrm{ha}$ ustawy dotyczącej COVID-19. Zgodnie z pierwszym ze wskazanych przepisów w okresie ogłoszenia stanu zagrożenia epidemicznego lub stanu epidemii pracownicy, jak również inne osoby zatrudnione poddane obowiązkowej kwarantannie, mogą - za zgodą pracodawcy lub zatrudniającego - świadczyć w trybie pracy zdalnej pracę określoną w umowie oraz otrzymywać z tego tytułu wynagrodzenie. Do warunków świadczenia takiej pracy należy stosować przepisy art. 3 ust. 3-8 ustawy dotyczącej COVID-19.

Wskazana regulacja została wprowadzona ustawą z dnia 28 października 2020 roku o zmianie niektórych ustaw w związku z przeciwdziałaniem sytuacjom kryzysowym związanym z wystąpieniem COVID-19 (Dz.U. 2020, poz. 2112 ze zm., zmieniona ustawą z dnia 28 października 2020 roku o zmianie ustawy o zmianie niektórych ustaw w związku z przeciwdziałaniem sytuacjom kryzysowym związanym z wystąpieniem COVID-19, Dz.U. 2020, poz. 2113) i weszła w życie z dniem 29 listopada $2020 \mathrm{roku}^{3}$. Na wstępie należy zauważyć, że regulacja ta odnosi się nie tylko do pracowników, ale także do osób zatrudnionych na podstawie innej niż stosunek pracy (w przypadku występowania podmiotu zatrudniającego; por. Siwiec 2020). Tak szerokie ujęcie strony podmiotowej jest o tyle istotne, że regulacja w sprawie pracy zdalnej zawarta $\mathrm{w}$ art. 3 ustawy dotyczącej COVID-19 odnosi się do pracowników ${ }^{4}$. Na podstawie art. 3 ust. 2

3 Przed wprowadzeniem niniejszej regulacji w literaturze przedmiotu zwracano uwagę na wątpliwości pracodawców co do możliwości wydania polecenia dotyczącego wykonywania obowiązków służbowych w czasie obowiązkowej kwarantanny i równocześnie na praktykę częstego wykonywania pracy zdalnej w czasie kwarantanny za zgodą obu stron (por. Podgórska-Rakiel 2020). Odpowiedzią na powyższe powinien być art. 6 ust. 2 ustawy zasiłkowej. Wydanie we wskazanej sytuacji polecenia dotyczącego wykonywania obowiązków służbowych w czasie obowiązkowej kwarantanny byłoby odzwierciedleniem zupełnego niezrozumienia istoty niezdolności do pracy z powodu choroby.

${ }_{4}$ Choć treść art. 3 ust. 1 ustawy dotyczącej COVID-19 wskazuje jedynie na pracowników zatrudnionych na podstawie umowy o pracę, uznać należy, że brak jakiegokolwiek uzasadnienia aksjologicznego, 
tej ustawy praca zdalna może być zlecana także funkcjonariuszom wskazanym w tym przepisie, do których regulację z art. 3 ust. 1 ustawy dotyczącej COVID-19 należy stosować odpowiednio. Przepisy mówiące o pracy zdalnej, zawarte w art. 3 ustawy dotyczącej COVID-19, nie odnoszą się jednak do osób świadczących pracę na podstawie umów cywilnoprawnych, choć strony mogą, co oczywiste, przewidywać odpowiednie postanowienia w tym zakresie zgodnie z ogólną zasadą swobody umów (Napiórkowska, Rutkowska 2021).

W kontekście art. 4h ustawy dotyczącej COVID-19 na uwagę zasługuje to, że wykonywanie pracy zdalnej w czasie obowiązkowej kwarantanny opiera się na zgodzie obydwu stron. Po stronie pracownika czy innej osoby zatrudnionej taka praca ma zawsze charakter fakultatywny, za każdym razem wymagana jest także zgoda pracodawcy lub innego podmiotu zatrudniającego.

W art. 4h ust. 1 ustawy dotyczącej COVID-19 ustawodawca wskazuje, że do warunków świadczenia takiej pracy należy stosować przepisy art. 3 ust. 3-8 ustawy dotyczącej COVID-19, choć - jak się wydaje - nie w każdym przypadku stosowana konstrukcja jest adekwatna do problematyki wykonywania pracy zdalnej w czasie obowiązkowej kwarantanny. Trudno bowiem mówić o poleceniu pracy zdalnej (a tym samym o cofnięciu polecenia) - chodzić może jedynie o zgodę na wykonywanie pracy w trybie pracy zdalnej (czy ewentualnie o cofnięcie takiej zgody) w czasie obowiązkowej kwarantanny. Może to oczywiście nastąpić w każdym czasie (art. 3 ust. 8 ustawy dotyczącej COVID-19). Wymóg dotyczący stosowania przepisów art. 3 ust. 3-8 ustawy dotyczącej COVID-19 sprowadza się do tego, że pracownik lub inna osoba zatrudniona powinna mieć umiejętności oraz możliwości techniczne i lokalowe do wykonywania pracy w takim trybie, powinien też na to pozwalać rodzaj pracy. Praca zdalna może być wykonywana przy wykorzystaniu środków bezpośredniego porozumiewania się na odległość bądź dotyczyć wykonywania części wytwórczych albo usług materialnych. Ten drugi aspekt wydaje się jednak mniej prawdopodobny - w związku z tym, że dana osoba przebywa na kwarantannie, jej aktywność poza miejscem kwarantanny nie jest możliwa (np. udanie się na pocztę). Zgodnie z regulacją dotyczącą pracy zdalnej narzędzia i materiały potrzebne do wykonywania takiej pracy oraz obsługę logistyczną powinien zapewnić pracodawca lub inny podmiot zatrudniający. Pracownik czy inna osoba zatrudniona może używać narzędzi bądź materiałów niezapewnionych przez pracodawcę lub dany podmiot zatrudniający, pod warunkiem że umożliwia to poszanowanie i ochronę informacji poufnych oraz innych tajemnic prawnie chronionych, w tym tajemnicy przedsiębiorstwa lub danych osobowych, jak również informacji, których ujawnienie mogłoby narazić dany podmiot na szkodę. Na polecenie pracodawcy lub innego podmiotu zatrudniającego pracownik lub inna osoba zatrudniona wykonująca pracę zdalną ma obowiązek prowadzić ewidencję wykonanych czynności, uwzględniającą w szczególności opis tych czynności, jak również

by wyłączać pracowników zatrudnionych na innych podstawach. Przyjąć więc należy, że praca zdalna, o której mowa w art. 3 ustawy dotyczącej COVID-19, odnosi się do wszystkich pracowników, niezależnie od podstawy nawiązania stosunku pracy (Napiórkowska, Rutkowska 2021). 
datę i czas ich wykonania. Osoby takie sporządzają również ewidencję wykonywanych czynności w formie określonej przez pracodawcę lub inny podmiot zatrudniający i ze wskazaną przezeń częstotliwością.

Z dniem 5 grudnia 2020 roku wprowadzono do ustawy dotyczącej COVID-19 analogiczną regulację (art. 4ha) odnoszącą się do możliwości świadczenia pracy w trybie pracy zdalnej w czasie obowiązkowej izolacji w warunkach domowych (por. art. 1 pkt 1 ustawy z dnia 27 listopada 2020 roku o zmianie ustawy o szczególnych rozwiązaniach związanych z zapobieganiem, przeciwdziałaniem i zwalczaniem COVID-19, innych chorób zakaźnych oraz wywołanych nimi sytuacji kryzysowych oraz niektórych innych ustaw, Dz.U. 2020, poz. 2157). Podobnie jak w przypadku pracy zdalnej w okresie obowiązkowej kwarantanny konstrukcja ta jest ograniczona czasowo - dotyczy jedynie okresu ogłoszenia stanu zagrożenia epidemicznego lub stanu epidemii. Regulacja ta odnosi się również do pracowników i innych osób zatrudnionych. Osoby te mogą - za zgodą pracodawcy albo innego podmiotu zatrudniającego - świadczyć w trybie pracy zdalnej pracę określoną w umowie i otrzymywać z tego tytułu wynagrodzenie. Do warunków świadczenia pracy w trybie zdalnym w czasie obowiązkowej izolacji w warunkach domowych należy stosować przepisy art. 3 ust. 3-8 ustawy dotyczącej COVID-19. $\mathrm{W}$ uzasadnieniu do wprowadzanych w tym przypadku zmian zwrócono uwagę na ewentualny problem deficytu pracowników w zakładach pracy w związku z wirusem COVID-19 i związane z tym zagrożenie dla ciągłości funkcjonowania zakładów pracy powodowane obowiązkową kwarantanną i izolacją w warunkach domowych. Analogicznie więc jak w przypadku obowiązkowej kwarantanny, również w czasie izolacji w warunkach domowych zaproponowano możliwość pracy zdalnej, wskazując, że wśród izolowanych osób zakażonych są także osoby niemające symptomów choroby COVID-19 bądź mające łagodne objawy. Zwrócono także uwagę na przewidywane mniejsze wydatki z Funduszu Ubezpieczeń Społecznych, zakładając oszczędności w wysokości około 58415092 zł (por. uzasadnienie do projektu ustawy o zmianie ustawy o szczególnych rozwiązaniach związanych z zapobieganiem, przeciwdziałaniem i zwalczaniem COVID-19, innych chorób zakaźnych oraz wywołanych nimi sytuacji kryzysowych oraz niektórych innych ustaw, druk sejmowy nr 772, s. 1-2 oraz ocena skutków regulacji, s. 4).

Zarówno w przypadku świadczenia pracy w trakcie obowiązkowej kwarantanny, jak i w czasie izolacji w warunkach domowych pracownikowi czy innej osobie zatrudnionej nie przysługuje wynagrodzenie chorobowe ani świadczenia ubezpieczeniowe związane z czasową niezdolnością do pracy (art. 4h ust. 2 oraz art. 4ha ust. 2 ustawy dotyczącej COVID-19). W tym czasie osoby te otrzymują wynagrodzenie w związku z wykonaną pracą. Zgodnie natomiast $\mathrm{z}$ art. $4 \mathrm{hb}$ tej ustawy za okres nieświadczenia pracy $\mathrm{w}$ trakcie kwarantanny bądź izolacji w warunkach domowych ubezpieczonym przysługuje wynagrodzenie chorobowe lub świadczenie pieniężne z tytułu choroby (chodzi, rzecz jasna, nie o chorobę, jak sugeruje przepis, ale o czasową niezdolność do pracy z powodu choroby). Wydaje się to oczywiste - są to bowiem sytuacje zrównane z niezdolnością do pracy z powodu choroby. Jeśli więc ubezpieczony spełnia przewidziane prawem warunki, ma prawo do określonych świadczeń. 
Czy zmiany w przepisach prawnych w związku z pandemią COVID-19 mogą być wskazówką do określonych przeobrażeń w zakresie analizowanej problematyki?

Na uwagę zasługuje przede wszystkim to, że ustawodawca dostrzegł możliwość wystąpienia takich sytuacji, w których ubezpieczony może wykonywać pracę zarobkową w pewnym ograniczonym zakresie w okresie podlegania obowiązkowej kwarantannie, jak również podczas izolacji w warunkach domowych. Może to potwierdzać istnienie potrzeby, by - już na etapie czasowej niezdolności do pracy (oraz sytuacji zrównanych $\mathrm{z}$ tą niezdolnością) lub w ramach świadczeń krótkoterminowych w ogóle - w niektórych przypadkach dostrzegać potrzebę pozytywnego orzekania przez uprawnione podmioty o zachowanych przez ubezpieczonego zdolnościach czy umiejętnościach

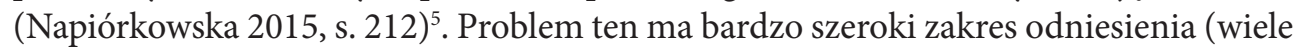
osób przebywa przecież na długotrwałych zwolnieniach lekarskich). Oczywiście kwestia ta wymaga dużej ostrożności, odpowiedniego wyważenia i pogłębionej dyskusji naukowej.

Wszystkie analizowane zmiany dokonywane w związku z pandemią COVID-19 były związane z nadzwyczajną sytuacją - przyjęte rozwiązania nie były więc ujmowane jako modelowe. Ustawodawca, obserwując występujące na dotąd niespotykaną skalę sytuacje związane z obowiązkową kwarantanną czy izolacją w warunkach domowych, odnosił się jedynie do tych sytuacji. Nie podjęto dalszych, bardziej radykalnych kroków. W dobie pandemii trudno było zresztą tego oczekiwać, zmiana taka musiałaby się bowiem wiązać z gruntowną reorganizacją systemu orzekania, który w Polsce jest dotknięty wieloma problemami.

W przypadku ubezpieczonych wykonujących zawód medyczny ustawodawca zastosował znacznie korzystniejszy system ochrony niż w odniesieniu do pozostałych ubezpieczonych. Mogli oni w określonym czasie świadczyć pracę zdalną na rzecz podmiotu wykonującego działalność leczniczą lub udzielać świadczeń zdrowotnych za pośrednictwem systemów teleinformatycznych bądź systemów łączności, równocześnie przebywając na obowiązkowej kwarantannie lub będąc w izolacji w warunkach domowych. W takim przypadku świadczenia kumulowały się, co budzi poważne wątpliwości. Jak się wydaje, bardziej optymalnym rozwiązaniem jest raczej odpowiednie równoważenie świadczeń. $\mathrm{Z}$ jednej strony więc chodziłoby o stworzenie możliwości prawnych dla pozytywnego orzekania przez uprawniony podmiot/podmioty (w ramach zmienionej formuły orzekania) o zachowanych przez ubezpieczonego zdolnościach czy umiejętnościach, z drugiej strony natomiast chodziłoby o bilansowanie „straty” w ramach ubezpieczeniowego systemu ochrony. Oczywiście wymagałoby to odpowiedniej podstawy prawnej, jak również fachowej oceny dokonywanej przez podmioty mające specjalistyczną wiedzę, zapewne nie tylko medyczną (Napiórkowska 2015, s. 212).

Jeśli chodzi o art. 17 ust. 1 ustawy zasiłkowej, to wydaje się, że optymalnym rozwiązaniem jest to, by utratę prawa do zasiłku chorobowego powodowało takie zachowanie ubezpieczonego, które w sposób oczywisty byłoby niezgodne z celem zwolnienia lekarskiego

5 Na podejście pozytywne, a nie negatywne (choć w znacznie szerszym kontekście) zwraca uwagę Stanisława Golinowska (2012, s. 450). Por. także Devetzi, Stendahl 2011. 
w postaci odzyskania zdolności do pracy (Napiórkowska 2015, s. 213) ${ }^{6}$. Przesłanka ta musiałaby zostać dookreślona w ramach praktyki orzeczniczej Sądu Najwyższego. Słowo „oczywisty” w sposób ewidentny eliminowałoby jednak pewne sytuacje, na przykład podejmowanie jedynie formalnych czynności, wymuszonych okolicznościami, które Sąd Najwyższy odróżnia od pracy zarobkowej - nie wyczerpywałoby tak skonstruowanej przesłanki (Napiórkowska 2015, s. 213). Pozwoliłoby to uniknąć zarzutu o brak ścisłego stosowania przepisów (Rzetecka-Gil 2008). Razem ze zmienionym systemem orzekania, opartym - choć w niektórych przypadkach - na pozytywnym orzekaniu o zachowanych przez ubezpieczonego zdolnościach czy umiejętnościach, tworzyłoby to bardziej kompleksowy, ale też bardziej elastyczny system ochrony, uwzględniający dostrzegalne potrzeby.

Na zakończenie - odnosząc się jeszcze do regulacji wprowadzonych w związku z COVID-19 - warto zauważyć, że pewne wątpliwości wzbudza kwestia, czy właściwym rozwiązaniem jest to, że ustawodawca łączy uprawnienia decyzyjne dotyczące wykonywania pracy (również w trybie zdalnym) w okresie obowiązkowej kwarantanny lub izolacji $\mathrm{w}$ warunkach domowych jedynie $\mathrm{z}$ wolą stron danego stosunku (a więc na poziomie tego stosunku prawnego). Wprawdzie w judykaturze zauważa się, że rezygnacja ze zwolnienia lekarskiego może się dokonać w dwojaki sposób: per facta concludentia - przez przyjście ubezpieczonego do pracy lub w sposób formalny - w drodze opinii lekarskiej, a także podkreśla się, że wykorzystanie zwolnienia lekarskiego jest prawem, a nie obowiązkiem ubezpieczonego (uchwała Sądu Najwyższego z dnia 17 lutego 2016 roku, III UZP 15/15), to jednak wydaje się, że w tych obszarach, w których chodzi o zdrowie i życie ludzkie, należy poszukiwać bardziej wyważonych rozwiązań, opierających się na fachowej ocenie dokonanej przez podmiot mający wiedzę medyczną. W prawie pracy należy pamiętać o tym, że to pracodawca odpowiada za stan bezpieczeństwa i higieny pracy w zakładzie pracy (art. $207 \S 1$ k.p.).

\section{Bibliografia}

Devetzi S., Stendahl S. (eds.) (2011) Too Sick to Work? Social Security Reforms in Europe for Persons with Reduced Earnings Capacity, Alphen aan den Rijn.

Golinowska S. (2012) [w:] S. Golinowska (red.), Instytucjonalne, zdrowotne i społeczne determinanty niepetnosprawności, Warszawa.

Jędrasik-Jankowska I. (1983) Zasiłek chorobowy (problematyka prawna), Warszawa.

Jędrasik-Jankowska I. (1997) Praktyczny komentarz do ustawy o zasiłkach z ubezpieczeń społecznych, „Przegląd Ubezpieczeń Społecznych i Gospodarczych”, nr 1.

Jędrasik-Jankowska I. (2018) Pojęcia i konstrukcje prawne ubezpieczenia społecznego, Warszawa. Jończyk J. (2006) Prawo zabezpieczenia społecznego, Kraków.

${ }^{6}$ Kwestie związane z problematyką orzekania, jak również problematyką dotyczącą art. 17 ustawy zasiłkowej zostały szerzej przeanalizowane w rozprawie doktorskiej Anny Napiórkowskiej (2014, s. 192-204). 
Napiórkowska A. (2014) Granice ochrony pracownika w razie czasowej niezdolności do pracy $z$ powodu choroby, Toruń [rozprawa doktorska].

Napiórkowska A. (2015) Świadczenia krótkoterminowe z ubezpieczenia wypadkowego [w:] A. Bałszan, M. Marczyk (red.), Ubezpieczenie społeczne z tytułu wypadków przy pracy, Warszawa-Toruń.

Napiórkowska A. (2021) COVID-19 a świadczenia z ubezpieczenia chorobowego (wybrane zagadnienia) [w:] Księga Jubileuszowa dedykowana Profesorowi B.M. Ćwiertniakowi [w druku].

Napiórkowska A., Rutkowska B. (2021) Remote Work: A Solution for COVID-19 Only or a Model for the Future? [w druku].

Piszczek A. (2020) [w:] K.W. Baran (red.), Komentarz do niektórych przepisów ustawy o szczególnych rozwiązaniach związanych z zapobieganiem, przeciwdziałaniem i zwalczaniem COVID-19, innych chorób zakaźnych oraz wywołanych nimi sytuacji kryzysowych [w:] Tarcza antykryzysowa 1.0-4.0. Ustawa o dodatku solidarnościowym i inne regulacje jako szczególne rozwiązania w prawie pracy, prawie urzędniczym i prawie ubezpieczeń społecznych zwiąane $z$ COVID-19. Komentarz, LEX.

Podgórska-Rakiel E. (2020) Praca zdalna na kwarantannie, LEX.

Rączka K. (2000) [w:] M. Gersdorf, M. Iżycka-Rączka, J. Jagielski, K. Rączka, Komentarz do ustawy o świadczeniach pieniężnych $z$ ubezpieczenia społecznego $w$ razie choroby lub macierzyństwa. Zasitki: chorobowy, rehabilitacyjny, wyrównawczy, porodowy, macierzyński, opiekuńczy, Warszawa.

Rzetecka-Gil A. (2008) Glosa do wyroku SN z dnia 15 czerwca 2007 r., II UK 223/06, LEX.

Siwiec M. (2020) Przeciwdziałanie sytuacjom kryzysowym związanym z COVID-19, LEX.

Szubert W. (1987) Ubezpieczenie społeczne. Zarys systemu, Warszawa.

\section{Orzecznictwo}

Uchwała Sądu Najwyższego z dnia 20 stycznia 1995 roku, II UZP 38/94, LEX nr 11965. Uchwała Sądu Najwyższego z dnia 17 lutego 2016 roku, III UZP 15/15, LEX nr 1977620. Wyrok Sądu Apelacyjnego w Poznaniu z dnia 24 kwietnia 1996 roku, III AUr 42/96, LEX nr 29603. Wyrok Sądu Najwyższego z dnia 12 sierpnia 1998 roku, II UKN 172/98, LEX nr 34553. Wyrok Sądu Najwyższego z dnia 10 grudnia 1998 roku, II UKN 367/98, LEX nr 38913. Wyrok Sądu Najwyższego z dnia 11 lutego 1999 roku, II UKN 467/98, LEX nr 477337. Wyrok Sądu Najwyższego z dnia 17 stycznia 2002 roku, II UKN 710/00, LEX nr 56864. Wyrok Sądu Najwyższego z dnia 7 października 2003 roku, II UK 76/03, LEX nr 109913. Wyrok Sądu Najwyższego z dnia 20 stycznia 2005 roku, II UK 154/04, LEX nr 175814. Wyrok Sądu Najwyższego z dnia 5 kwietnia 2005 roku, I UK 370/04, LEX nr 157330. Wyrok Sądu Najwyższego z dnia 5 października 2005 roku, I UK 44/05, LEX nr 195532. Wyrok Sądu Najwyższego z dnia 14 grudnia 2005 roku, III UK 120/05, LEX nr 201295. Wyrok Sądu Najwyższego z dnia 9 października 2006 roku, II UK 44/06, LEX nr 309449. Wyrok Sądu Najwyższego z dnia 6 lutego 2008 roku, II UK 10/07, LEX nr 493009. Wyrok Sądu Najwyższego z dnia 6 maja 2009 roku, II UK 359/08, LEX nr 687081. Wyrok Sądu Najwyższego z dnia 14 maja 2009 roku, I UK 351/08, LEX nr 515410. 
Wyrok Sądu Najwyższego z dnia 4 listopada 2009 roku, I UK 140/09, LEX nr 564767.

Wyrok Sądu Najwyższego z dnia 4 kwietnia 2012 roku, II UK 186/11, LEX nr 1216851.

\section{Akty prawa krajowego}

Ustawa z dnia 26 czerwca 1974 roku - Kodeks pracy, Dz.U. 2020, poz. 1320 tekst jedn. ze zm. Ustawa z dnia 17 grudnia 1974 roku o świadczeniach pieniężnych z ubezpieczenia społecznego w razie choroby i macierzyństwa, Dz.U. 1974, nr 47, poz. 280 ze zm.

Ustawa z dnia 25 czerwca 1999 roku o świadczeniach pieniężnych z ubezpieczenia społecznego w razie choroby i macierzyństwa, Dz.U. 2021, poz. 1133 tekst jedn.

Ustawa z dnia 12 marca 2004 roku o pomocy społecznej, Dz.U. 2020, poz. 1876 tekst jedn. ze zm. Ustawa $\mathrm{z}$ dnia 5 grudnia 2008 roku o zapobieganiu oraz zwalczaniu zakażeń i chorób zakaźnych u ludzi, Dz.U. 2020, poz. 1845 tekst jedn. ze zm.

Ustawa z dnia 15 kwietnia 2011 roku o działalności leczniczej, Dz.U. 2021, poz. 711 tekst jedn. ze zm.

Ustawa z dnia 9 czerwca 2011 roku o wspieraniu rodziny i systemie pieczy zastępczej, Dz.U. 2020, poz. 821 tekst jedn. ze zm.

Ustawa z dnia 2 marca 2020 roku o szczególnych rozwiązaniach związanych z zapobieganiem, przeciwdziałaniem i zwalczaniem COVID-19, innych chorób zakaźnych oraz wywołanych nimi sytuacji kryzysowych, Dz.U. 2020, poz. 1842 tekst jedn. ze zm.

Ustawa z dnia 14 maja 2020 roku o zmianie niektórych ustaw w zakresie działań osłonowych w związku z rozprzestrzenianiem się wirusa SARS-CoV-2, Dz.U. 2020, poz. 875 ze zm.

Ustawa z dnia 28 października 2020 roku o zmianie niektórych ustaw w związku z przeciwdziałaniem sytuacjom kryzysowym związanym z wystąpieniem COVID-19, Dz.U. 2020, poz. 2112 ze zm.

Ustawa z dnia 27 listopada 2020 roku o zmianie ustawy o szczególnych rozwiązaniach związanych z zapobieganiem, przeciwdziałaniem i zwalczaniem COVID-19, innych chorób zakaźnych oraz wywołanych nimi sytuacji kryzysowych oraz niektórych innych ustaw, Dz.U. 2020, poz. 2157. Zarządzenie Ministra Pracy, Płac i Spraw Socjalnych z dnia 30 grudnia 1974 roku w sprawie kontroli prawidłowości wykorzystywania zwolnień lekarskich od pracy, M.P. 1974, nr 42, poz. 263.

\section{Inne}

Uzasadnienie do projektu ustawy o zmianie niektórych ustaw w zakresie działań osłonowych w związku z rozprzestrzenianiem się wirusa SARS-CoV-2 (2020), druk sejmowy nr 344, Sejm IX kadencji, https://www.sejm.gov.pl/sejm9.nsf/PrzebiegProc.xsp?nr=344 (dostęp: 11 lipca 2021).

Uzasadnienie do projektu ustawy o zmianie ustawy o szczególnych rozwiązaniach związanych z zapobieganiem, przeciwdziałaniem i zwalczaniem COVID-19, innych chorób zakaźnych oraz wywołanych nimi sytuacji kryzysowych oraz niektórych innych ustaw (2020), druk sejmowy nr 772, Sejm IX kadencji, https://www.sejm.gov.pl/Sejm9.nsf/druk.xsp?nr=772 (dostęp: 11 lipca 2021). 